\title{
Optimized method for extraction of exosomes from human primary muscle cells
}

\author{
Laura Le Gall ${ }^{1 \dagger}$, Zamalou Gisele Ouandaogo ${ }^{2 \dagger}$, Ekene Anakor ${ }^{1 \dagger}$, Owen Connolly ${ }^{1}$, Gillian Butler Browne 2 ,
} Jeanne Laine ${ }^{2}$, William Duddy ${ }^{1}$ and Stephanie Duguez ${ }^{1 *}$

\begin{abstract}
Skeletal muscle is increasingly considered an endocrine organ secreting myokines and extracellular vesicles (exosomes and microvesicles), which can affect physiological changes with an impact on different pathological conditions, including regenerative processes, aging, and myopathies. Primary human myoblasts are an essential tool to study the muscle vesicle secretome. Since their differentiation in conditioned media does not induce any signs of cell death or cell stress, artefactual effects from those processes are unlikely. However, adult human primary myoblasts senesce in long-term tissue culture, so a major technical challenge is posed by the need to avoid artefactual effects resulting from pre-senescent changes. Since these cells should be studied within a strictly controlled pre-senescent division count (<21 divisions), and yields of myoblasts per muscle biopsy are low, it is difficult or impossible to amplify sufficiently large cell numbers (some $250 \times 10^{6}$ myoblasts) to obtain sufficient conditioned medium for the standard ultracentrifugation approach to exosome isolation.

Thus, an optimized strategy to extract and study secretory muscle vesicles is needed. In this study, conditions are optimized for the in vitro cultivation of human myoblasts, and the quality and yield of exosomes extracted using an ultracentrifugation protocol are compared with a modified polymer-based precipitation strategy combined with extra washing steps. Both vesicle extraction methods successfully enriched exosomes, as vesicles were positive for CD63, CD82, CD81, floated at identical density (1.15-1.27 g.ml $\left.{ }^{-1}\right)$, and exhibited similar size and cup-shape using electron microscopy and NanoSight tracking. However, the modified polymer-based precipitation was a more efficient strategy to extract exosomes, allowing their extraction in sufficient quantities to explore their content or to isolate a specific subpopulation, while requiring $>30$ times fewer differentiated myoblasts than what is required for the ultracentrifugation method. In addition, exosomes could still be integrated into recipient cells such as human myotubes or iPSC-derived motor neurons.

Modified polymer-based precipitation combined with extra washing steps optimizes exosome yield from a lower number of differentiated myoblasts and less conditioned medium, avoiding senescence and allowing the execution of multiple experiments without exhausting the proliferative capacity of the myoblasts.
\end{abstract}

Keywords: Extracellular vesicle, Muscle exosome extraction in vitro, Muscle secretome

\footnotetext{
*Correspondence: s.duguez@ulster.ac.uk

†Laura Le Gall, Zamalou Gisele Ouandaogo and Ekene Anakor contributed equally to this work.

${ }^{1}$ Northern Ireland Center for Stratified/Personalised Medicine, Biomedical Sciences Research Institute, Ulster University, Derry Londonderry, UK

Full list of author information is available at the end of the article
}

(C) The Author(s). 2020 Open Access This article is licensed under a Creative Commons Attribution 4.0 International License, which permits use, sharing, adaptation, distribution and reproduction in any medium or format, as long as you give appropriate credit to the original author(s) and the source, provide a link to the Creative Commons licence, and indicate if changes were made. The images or other third party material in this article are included in the article's Creative Commons licence, unless indicated otherwise in a credit line to the material. If material is not included in the article's Creative Commons licence and your intended use is not permitted by statutory regulation or exceeds the permitted use, you will need to obtain permission directly from the copyright holder. To view a copy of this licence, visit http://creativecommons.org/licenses/by/4.0/. The Creative Commons Public Domain Dedication waiver (http://creativecommons.org/publicdomain/zero/1.0/) applies to the data made available in this article, unless otherwise stated in a credit line to the data. 


\section{Introduction}

In addition to its classical role in locomotion, skeletal muscle is increasingly recognized to have a role in signaling via its secretory functions. Interleukin-6 (IL-6) [1] and musculin [2] have been identified to originate and be secreted from skeletal muscle in vivo, and the secretomic profiles of muscle cells in vitro, such as $\mathrm{C}_{2} \mathrm{C}_{12}$ myotubes [3, 4], human myotubes [5], and rat muscle explants [6] include growth factors (e.g., follistatin-like protein 1, IGF2, TGF), cytokines, and inhibitors of collagenase (e.g., TIMP2). These studies suggest that skeletal muscle can be viewed as an endocrine organ. Secreted proteins - also named myokines [2] - may act in an autocrine/paracrine manner on muscle cells or other types of cell and contribute to muscle growth and regeneration, body-wide metabolism, and other functions [see [7] for review].

In addition to proteins exiting the cell by classical secretory pathways, muscle cells also release proteinassociated vesicles [5]. These extracellular vesicles (EVs) are widely studied in different physiological and pathological contexts, and are known to play a key role in tissue homeostasis [8], embryogenesis and development [9], cell survival [10], inflammatory and metabolic diseases [11, 12], cancer metastasis [13]. EVs are broadly classified as exosomes, ectosomes, or apoptotic bodies. Exosomes (40-120 nm) are formed from the endolysosomal pathway and are released into the extracellular space when multivesicular bodies containing intraluminal vesicles undergo exocytosis [14]. Ectosomes (100-1000 nm) encompass microvesicles, microparticles, or shedding vesicles and are formed from the direct budding of the plasma membrane [15]. Finally, apoptotic bodies (500$2000 \mathrm{~nm}$ ) result from the outward bulge of the cell membrane due to cytoskeleton dysfunction and usually contain a part of the cytoplasm [16]. Human skeletal muscle cells are known to secrete two categories of veisicle, exosomes, and microvesicles [5]. Both types of muscle cell vesicles can fuse and deliver functional proteins into target cells, as shown by the delivery of alkaline phosphatase through vesicles to human dermofibroblasts that do not have an endogenous activity for alkaline phosphatase [5]. Exosomes and microvesicles from other cell types have been described to play a role in intercellular communication and to induce physiological changes in recipient cells, such as induction of cellular oncogenic transformation [17] or T-cell activation [18]. While the role of cytokines (e.g., [19-21]) and vesicles (e.g., [18, 22]) originating from inflammatory cells is well documented, the role of their secretion by myoblasts or differentiating myotubes is relatively unexplored, particularly concerning regenerative processes in injury and aging, and inflammatory and fibrotic processes in various muscle pathologies. Primary human myoblasts obtained from muscle biopsies are an invaluable in vitro tool for studying a pure human muscle secretome but this poses a technical challenge relating to the volume of conditioned media required per data point and their limited proliferative capacity [23]. Since primary human myoblasts should be studied within a strictly controlled pre-senescent division count ( $<21$ divisions), and yields of myoblasts per muscle biopsy can be low, it can be difficult or impossible to amplify sufficiently large cell numbers (some $250 \times 10^{6}$ myoblasts) to obtain sufficient conditioned medium for certain approaches to exosome isolation.

The isolation of exosomes from cell culture have been achieved by ultracentrifugation-based methods [24, 25], size-based techniques [24, 26, 27], polymer-based precipitation [28], and immunoaffinity capture-based techniques [24]. Ultracentrifugation is considered the gold standard and is the most reported exosome isolation technique [29]. However, ultracentrifugation has several shortcomings including the need for a large volume of biological fluid or conditioned cell culture media, long run-time, and limited reproducibility [30].

In this study, we highlight the challenges surrounding the study of vesicles secreted by primary human muscle cells and we compare two strategies-(1) ultracentrifugationbased isolation and (2) a modified polymer-based precipitation approach-in terms of quality and yield of exosomes. We define an optimized protocol to extract exosomes from primary muscle cells, without exhausting the number of pre-senescent divisions and thereby enabling a larger number of experiments to be carried out on a given cell line.

\section{Materials and methods}

\section{Primary cell extractions}

Six deltoid muscle biopsies were obtained from ALS patients $(50.0 \pm 6.5$ years old $)$ who attended the Motor Neuron Diseases Center (Pitié Salpétrière, Paris), and 17 muscle biopsies from healthy subjects $(51.4 \pm 18.2$ years old) from the BTR (Bank of Tissues for Research, a partner in the EU network EuroBioBank) in accordance with European recommendations and French legislation. The protocol (NCT01984957) was approved by the local Ethical Committee. Written informed consent was obtained from all patients. All biopsies were isolated from the deltoid muscle.

\section{Cell culture proliferation and differentiation}

Primary human myoblasts were extracted from fresh muscle biopsies as described previously [31]. Briefly, myoblasts were sorted using CD56 magnetic beads (Milteny ${ }^{\circ}$ ) and expanded in $0.22-\mu \mathrm{m}$ filtered proliferating medium containing DMEM/M199 medium supplemented with $20 \% \mathrm{FBS}, 25 \mu \mathrm{g} / \mathrm{ml}$ Fetuin, $0.5 \mathrm{ng} / \mathrm{ml} \mathrm{bFGF}$, $5 \mathrm{ng} / \mathrm{ml} \mathrm{EGF}, 5 \mu \mathrm{g} / \mathrm{ml}$ insulin and incubated at $5 \% \mathrm{CO}_{2}$, $37^{\circ} \mathrm{C}$. The number of cell divisions was calculated using 
the formula below. The myogenicity of the culture was determined by counting the number of nuclei positive for desmin against the total number of nuclei using the primary antibody anti-desmin (D33, 1:100, Dako). The secondary antibody was goat anti-mouse IgG1 AlexaFluor 594 (1:400, Invitrogen $\left.{ }^{\mathrm{Tx}}\right)$, and counterstaining was performed with $1 \mu \mathrm{g} \cdot \mathrm{ml}^{-1}$ DAPI as described below. After CD56 MACS sorting, $91.78 \pm 8.32 \%$ of the cells were myogenic.

$$
\text { Division number }=\frac{\log \left(\frac{\text { Cell number at day } n}{\text { Cell number plated }}\right)}{\log 2}
$$

For differentiation into myotubes, $7.5 \times 10^{6}$ myoblasts were plated in $225 \mathrm{~cm}^{2}$ flask (Falcom ${ }^{\mathrm{Tm}}$ ) and let adhere overnight. Seeded myoblasts were then washed six times with supplement free DMEM and differentiated in DMEM for $72 \mathrm{~h}$. The conditioned medium was then collected and used for exosome extraction.

\section{Beta-galactosidase staining}

The senescence level was assessed using a Senescence $\beta$ Galactosidase Staining Kit (Cell Signaling Technology ${ }^{\circ}$.

\section{Cell immunostaining}

The cells were fixed with $3.6 \%$ formaldehyde, permeabilized, blocked, and stained as described previously [32]. Primary antibody anti-myosin heavy chain (MF20, $1: 50$, DSHB) and secondary antibody goat anti-mouse IgG2b AlexaFluor 594 (1:400, Invitrogen $\left.{ }^{\mathrm{Tm}}\right)$ were used to determine the formation of myotubes. The slides were washed and counter-stained with $1 \mu \mathrm{g} \cdot \mathrm{ml}^{-1}$ DAPI for 2 min and then rinsed twice with PBS before being mounted with ibidi mounting medium (ibidi ${ }^{\circ}$ ).

\section{Protein extraction from cells}

Myoblasts were scraped into $50 \mu \mathrm{l}$ of chilled RIPA lysis buffer $\left(\right.$ Invitrogen $\left.{ }^{\mathrm{Tm}}\right)$ supplemented with $1 \times$ Halt $^{\mathrm{Tm}}$ protease inhibitor cocktail (Thermo Scientific ${ }^{\mathrm{mm}}$ ) and incubated on ice for $10 \mathrm{~min}$. Cell lysates were then centrifuged at $14,000 \mathrm{~g}$ for $10 \mathrm{~min}$ at $4{ }^{\circ} \mathrm{C}$ and protein supernatants were collected and stored at $-80^{\circ} \mathrm{C}$ for downstream SDSPAGE and immunoblotting.

\section{Condition culture media clearance}

At the time of collection, the conditioned medium is centrifuged at $200 \mathrm{~g}$ for $10 \mathrm{~min}$. The subsequent supernatant was then centrifuged at $4000 \mathrm{~g}$ for $20 \mathrm{~min}$. The resulting supernatant was centrifuged for $70 \mathrm{~min}$ at $4{ }^{\circ} \mathrm{C}$ at $20,000 \mathrm{~g}$ and then filtered through a $0.22-\mu \mathrm{m}$ filter. The cleared medium was then stored at $-80^{\circ} \mathrm{C}$ prior to exosome extraction.

\section{Muscle exosome extraction using ultracentrifugation}

Cleared media were centrifuged at $100,000 \mathrm{~g}$ for $70 \mathrm{~min}$ at $4{ }^{\circ} \mathrm{C}$ following a method described previously [24]. The subsequent pellet was resuspended in PBS and washed three times by centrifugation at $100,000 \mathrm{~g}$ for $70 \mathrm{~min}$ at $4{ }^{\circ} \mathrm{C}$. The clean pellet was then resuspended in $100 \mu \mathrm{l}$ of PBS or in NuPAGE ${ }^{\mathrm{m}}$ LDS sample buffer for Western blot experiments.

\section{Exosome extraction using polymer precipitation}

Cleared culture media was mixed with the Total Exosome Isolation kit (LifeTechnologies ${ }^{\mathrm{mm}}$ ) at a 2:1 volume ratio and incubated at $4{ }^{\circ} \mathrm{C}$ overnight. The mixture was then centrifuged at $10,000 \mathrm{~g}$ for $60 \mathrm{~min}$ at $4{ }^{\circ} \mathrm{C}$. The subsequent pellet was resuspended in $500 \mu \mathrm{l}$ of PBS and washed three times using $100 \mathrm{kDa}$ Amicon $^{\circ}$ filter column. The exosomes were then resuspended in $100 \mu \mathrm{l}$ of PBS or in NuPAGE ${ }^{\text {ma }}$ LDS sample buffer for Western blot experiments.

\section{Exosome protein extraction}

Exosomes were lysed in $8 \mathrm{M}$ urea supplemented with $1 \times$ Halt $^{\mathrm{mm}}$ Protease Inhibitor cocktail (Thermo Scientif ${ }^{\mathrm{Tm}}$ ) and $2 \%$ SDS. Samples were incubated at $4{ }^{\circ} \mathrm{C}$ for $15 \mathrm{~min}$, and exosome lysates were centrifuged at $14,000 \mathrm{~g}$ for 10 min at $4{ }^{\circ} \mathrm{C}$. Supernatants containing soluble proteins were stored at $-80^{\circ} \mathrm{C}$.

\section{SDS-PAGE and Western blotting}

SDS-PAGE was performed as follows. For cell lysates, protein concentrations were measured at $562 \mathrm{~nm}$ using the bicinchoninic acid assay kit $\left(\right.$ Pierce $^{\mathrm{Tm}}$ ) and $20 \mu \mathrm{g}$ of protein was mixed with $4 \times \mathrm{NuPAGE}^{\mathrm{m}}$ LDS sample buffer. For exosome extracts, proteins were also mixed with $4 \times$ NuPAGE $^{\mathrm{Tn}}$ LDS sample buffer. For reducing conditions, samples were supplemented with $10 \times \mathrm{NuPAGE}^{\mathrm{mm}}$ reducing agent. For the immunoblotting of tetraspanins, samples were prepared similarly but for the omission of reducing agents. All samples were then denatured at $70{ }^{\circ} \mathrm{C}$ for $10 \mathrm{~min}$ before being added to a $4-12 \%$ polyacrylamide Bis-Tris gel (Life Technologies ${ }^{\mathrm{Tm}}$ ) and electrophoresed at $200 \mathrm{v}$ for $70 \mathrm{~min}$ in MOPS SDS Running buffer (LifeTechnologies ${ }^{\mathrm{Tm}}$ ). Following electrophoresis, the gel was incubated in $20 \%$ ethanol for $10 \mathrm{~min}$ and proteins were transferred onto polyvinylidene fluoride membrane using the iBlot ${ }^{\text {tw }} 2$ Dry Blotting system (LifeTechnologies $\left.{ }^{\mathrm{TN}}\right)$ according to manufacturer's instructions.

Immunoblotting was performed using the Bind $^{\text {Tw }}$ Flex western system following the manufacturer's instructions (Life Technologies $\left.{ }^{\mathrm{Tm}}\right)$. PVDF membrane was probed with primary antibodies forPARP-1 (9542, Cell Signaling, rabbit IgG, 1:1000), or CD63 TS63 (10628D, Life Technologies $^{\mathrm{Tn}}$, mouse, $2 \mu \mathrm{g} / \mathrm{ml}$ ), or CD81 (MA5-13548, Life Technologies $^{\mathrm{Tw}}$, mouse IgG, 1:100, v:v dilution), Flotillin 
(PA5-18053, Life Technologies ${ }^{\text {tix }}, 0.3 \mu \mathrm{g} / \mathrm{ml}$ ) or HSPA8 (MABE1120, Millipore, mouse IgG, 1:1000) or Alix (SC-53540, Santa Cruz, 1:1000) and Goat anti-mouse or Goat anti-rabbit secondaries conjugated with HRP (LifeTechnologies $^{\mathrm{Tm}}$, 1:400, and 1:10,000 respectively). The membrane was then incubated with Amersham ECL Prime Western Blotting Detection Reagent for 5 minutes at room temperature and images were subsequently acquired using the UVP ChemiDoc- $\mathrm{It}^{\mathrm{t}+} 2$ Imager and UVP software.

\section{Electron microscopy and immunogold}

Extracted and further whole-mounted vesicles were processed as described in [24]. Observations were made using a CM120 transmission electron microscope (Philips, Eindhoven, The Netherlands) at $80 \mathrm{kV}$ and images recorded with a Morada digital camera (Olympus Soft Imaging Solutions GmbH, Münster, Germany).

\section{Determination of the exosome density}

Exosomes extracted from the cell culture medium using either ultracentrifugation or polymer-based precipitation were resuspended in $100 \mu \mathrm{l}$ of PBS and loaded on the top of the sucrose gradient as previously described [5, 32]. Samples were then centrifuged at $100,000 \mathrm{~g}$ for $17 \mathrm{~h}$ at $4{ }^{\circ} \mathrm{C}$. Twelve fractions were sequentially collected, diluted in $12 \mathrm{ml}$ PBS and centrifuged at $100,000 \mathrm{~g}$ for $70 \mathrm{~min}$ at $4{ }^{\circ} \mathrm{C}$. Each pellet was then resuspended in non-reducing NuPAGE $^{\mathrm{max}}$ LDS sample buffer and used for western blot analyses as described above. The density gradient of each fraction was determined using the method described by [33] by measuring the absorbance at $244 \mathrm{~nm}$ :

$$
\operatorname{Density}\left(\mathrm{g} \cdot \mathrm{cm}^{-3}\right)=\frac{\text { Absorbance at } 244 \mathrm{~nm}+5.7283}{5.7144}
$$

\section{Nanoparticle tracking analysis (NTA)}

Exosome pellets were resuspended in $100 \mu \mathrm{l}$ of filtered PBS. The exosome suspension was then diluted $10 x$ in PBS. The size and distribution of exosomes secreted by primary muscle cells were evaluated by a NanoSight LM10 instrument (NanoSight) equipped with NTA analytic software (version 2.3 build 2.3.5.0033.7-Beta7). Three videos of $30 \mathrm{~s}$ were as previously described $[34,35]$ at the temperature set to $22.5^{\circ} \mathrm{C}$. The minimum particle size, track length, and blur were set to "automatic".

\section{Proteomic analysis}

- The exosome pellets were re-suspended in $25 \mu \mathrm{l} 8 \mathrm{M}$ Urea, $50 \mathrm{mM}$ ammonium bicarbonate, $\mathrm{pH} 8.5$, and reduced with DTT for $1 \mathrm{~h}$ at $4{ }^{\circ} \mathrm{C}$. Protein concentrations were then quantified using Pierce BCA
Protein Assay kit (ThermoFisher $\left.{ }^{\circ}\right)$. Exosomal proteins were kept at $-80^{\circ} \mathrm{C}$.

- Proteome profile determined by mass spectrometry-20 $\mu \mathrm{g}$ of exosome protein were trypsin digested using a SmartDigest column (Thermo) for $2 \mathrm{~h}$ at $70^{\circ} \mathrm{C}$ and centrifugated at 1400 rpm. Peptides were then fractionated into 8 fractions using a high $\mathrm{pH}$ reverse phase spin column (Thermo). Fractioned peptides were vacuum dried, resuspended, and analysed by data-dependent mass spectrometry on a Q Exactive HF (Thermo) with the following parameters: Positive Polarity, m/z 4002000 MS Resolution 70,000, AGC 3e6, 100 ms IT, MS/MS Resolution 17,500, AGC 5e5, 50 ms IT, Isolation width $3 \mathrm{~m} / \mathrm{z}$, and NCE 30, cycle count 15 .

- Database search and quantification-The MS raw data sets were searched for protein identification for semi-tryptic peptides against the Uniprot human database for semi tryptic peptides including common contaminants, using MaxQuant software (version 1.6.2.1) (https://wSww.biochem.mpg.de/5111795/ maxquant). We used default parameters for the searches: mass tolerances were set at $\pm 20 \mathrm{ppm}$ for first peptide search and $\pm 4.5 \mathrm{ppm}$ for main peptide search, maximum two missed cleavage, and the peptide and resulting protein assignments were filtered based on a $1 \%$ protein false discovery rate (thus $99 \%$ confidence level). A total of 1254 proteins were detected in at least 1 sample. The mass spectrometry proteomics data have been deposited to the ProteomeXchange Consortium via the PRIDE partner repository with the dataset identifier PXD015736.

- To test for overlap with known exosome proteins from previous studies, all proteins detected in at least 1 proteomic sample were entered into the Funrich tool for vesicle functional analysis [36-39], and a Venn diagram generated against the subset of the Vesiclepedia database comprising previously observed exosomal proteins detected by mass spectrometry in human samples.

\section{mRNA extraction from polymer precipitated exosomes} Exosomes were first dissolved in $900 \mu \mathrm{l} \mathrm{TRIzol}{ }^{\circ}$ (Invitrogen $\left.^{\mathrm{Tm}}\right)$, then $200 \mu \mathrm{l}$ of chloroform was added. After $5 \mathrm{~min}$ of incubation at RT, samples were centrifuged at $12,000 \mathrm{~g}$ for $15 \mathrm{~min}$ at $4{ }^{\circ} \mathrm{C}$. The aqueous phase containing the RNA was transferred into a collection and mixed with $75 \%$ ethanol (1:1, v:v). mRNA was then purified using PureLink $^{\oplus}$ RNA Mini Kit (LifeTechologies ${ }^{\mathrm{Tm}}$ ) following the manufacturer's instructions. RNA eluates were stored at $-80^{\circ} \mathrm{C}$ until use. The concentration of each RNA sample was determined by NanoDrop spectrophotometer ND1000 (NanoDrop Technologies, Wilmington, DE). The quality of RNA samples was assessed with the Agilent 
2100 Bioanalyzer (Agilent Technologies Inc., Santa Clara, CA).

Immunoprecipitation of muscle exosome subpopulation Polymer-precipitated exosomes were immunoprecipitated using anti-CD63 magnetic beads (Invitrogen ${ }^{\mathrm{Tm}}$ ) overnight according to the manufacturer's instructions. Magnetically captured beads were then washed 3 times in PBS and CD63 positive exosomes were eluted in $4 \times$ NuPAGE $^{\mathrm{m}}$ LDS sample buffer. Samples were then used for western blot analyses as described above.

\section{Exosome functionality assessment}

The exosomes were labeled with the PKH26 kit (Sigma-Aldrich ${ }^{\circ}$ ). Briefly, $100 \mu \mathrm{l}$ of Diluent $\mathrm{C}$ was added to the exosome suspension and labeled with $100 \mu \mathrm{l}$ of $4 \mu \mathrm{M}$ PKH26 solution. After $5 \mathrm{~min}$ of incubation, samples were washed 3 times in PBS using a $100 \mathrm{kDa}$ Amicon $^{\circ}$ filter column and centrifuged at 12, $000 \times g$ at $4{ }^{\circ} \mathrm{C}$ for $15 \mathrm{~min}$. Muscle exosomes extracted from 3000 differentiated myoblasts were either added to 3000 human iPSC-derived motor neurons or to 3000 differentiated human myoblasts. Human iPSCderived motor neurons were differentiated from human neuron progenitors as described in [40]. Uptake of muscle exosomes by recipient cells was observed after 24-h incubation in living cells using an Olympus IX170 inverted microscope, with a $40 \times / 0.60 \mathrm{Ph} 2$ objective equipped with an AxiocamMR camera.

\section{Statistical analysis}

All values are presented as means $\pm \mathrm{SD}$. ANOVA 1 Factor followed by Tukey post-hoc test was used to compare the differences between the different cell densities conditions. Differences were considered to be statistically different at $P<0.05$.

\section{Results and discussion}

Determination of the window of cell divisions suitable to study the muscle secretome in non-senescent stages

Previously published studies on muscle cells using the ultracentrifugation method $[5,32]$ showed that $250 \times$ $10^{6}$ cells were needed in order to have enough material for 1 single data point for proteomic and transcriptomic analysis. However, primary muscle cells can only execute a limited number of divisions, $\sim 30-40$ divisions with several outliers as low as 22 divisions (Fig. 1a, b, [31]), before they stop dividing and become senescent. The maximum number of divisions is not age-dependent, which is consistent with our previous study showing that the myoblasts extracted from subjects have the same proliferative capacity as myoblasts extracted from young adults [41] (Fig. 1b). Senescent cells can secrete factors including exosomes that can impact surrounding cells as observed with senescent endothelial cells [42], cerebroendothelial cells [43], or fibroblasts [44]. In order to avoid potential artifacts arising from cells that are nearing, or have reached senescence, we suggest that myoblasts under 21 divisions should be used to study the muscle secretome (Fig. 1), and we, therefore, sampled cells within this window for all subsequent experiments.

\section{Optimization of the muscle cell culture conditions}

Muscle exosomes were extracted from myoblasts that had undergone between 16 and 20 divisions, seeded at a density of 33,400 cells. $\mathrm{cm}^{-2}$, and that were differentiated into myotubes for 3 days. Ninety-five percent of the myoblasts were differentiated into myotubes in DMEM after 3 days (Fig. $2 \mathrm{a}-\mathrm{c}$ ), covering over $\sim 80 \%$ of the petri dish (Fig. 2 d,e). Differentiated myoblasts were negative for Beta-galactosidase (Fig. 2d), confirming that they were not in a senescent state. Neither necrosis nor apoptosis was observed as PARP-1B was not cleaved (Fig. 2e). These data suggest that human muscle myoblasts which have made less than 20 divisions can differentiate efficiently into myotubes, are not senescent, and are therefore suitable for the study of the myotube secretome.

\section{Optimization of muscle exosome extraction}

Myoblasts were seeded at $7.5 \times 10^{6}$ cells per $225 \mathrm{~cm}^{2}$ flask. Due to the large volume of medium ( $250 \mathrm{ml}$ per sample) required for ultracentrifugation, a total of 14 flasks, thus 100 million differentiated myoblasts, were cultured per datapoint and per experiment to compare the efficacy of the ultracentrifugation and polymer-based precipitation protocols. Myotubes were maintained in conditioned media for 3 days. After pre-clearing the media, as described in the materials and methods and as shown in Fig. 3, exosomes were extracted using either the ultracentrifugation strategy or polymer-based precipitation. Previous publications showed lower exosomal protein detection (e.g., CD63) by Western blot using the polymer-based precipitation compared to ultracentrifugation, despite observing a greater number of vesicles by NanoSight using polymer-based precipitation $[28,45]$. Based on these publications, we suspected that the polymer matrix was hiding epitopes. After rinsing the exosome extracts 3 times with PBS in $100 \mathrm{kDa}$ Amicon $^{\circ}$ filter columns, the accessibility of antibodies to epitopes was rescued (Fig. 3).

The ultracentrifugation-based and modified polymerbased precipitation approaches both extract exosomes from conditioned cultured media of primary human myotubes, but the polymer-based approach is more efficient

Exosomes secreted by $100 \times 10^{6}$ differentiated myoblasts and extracted using either ultracentrifugation or polymer- 


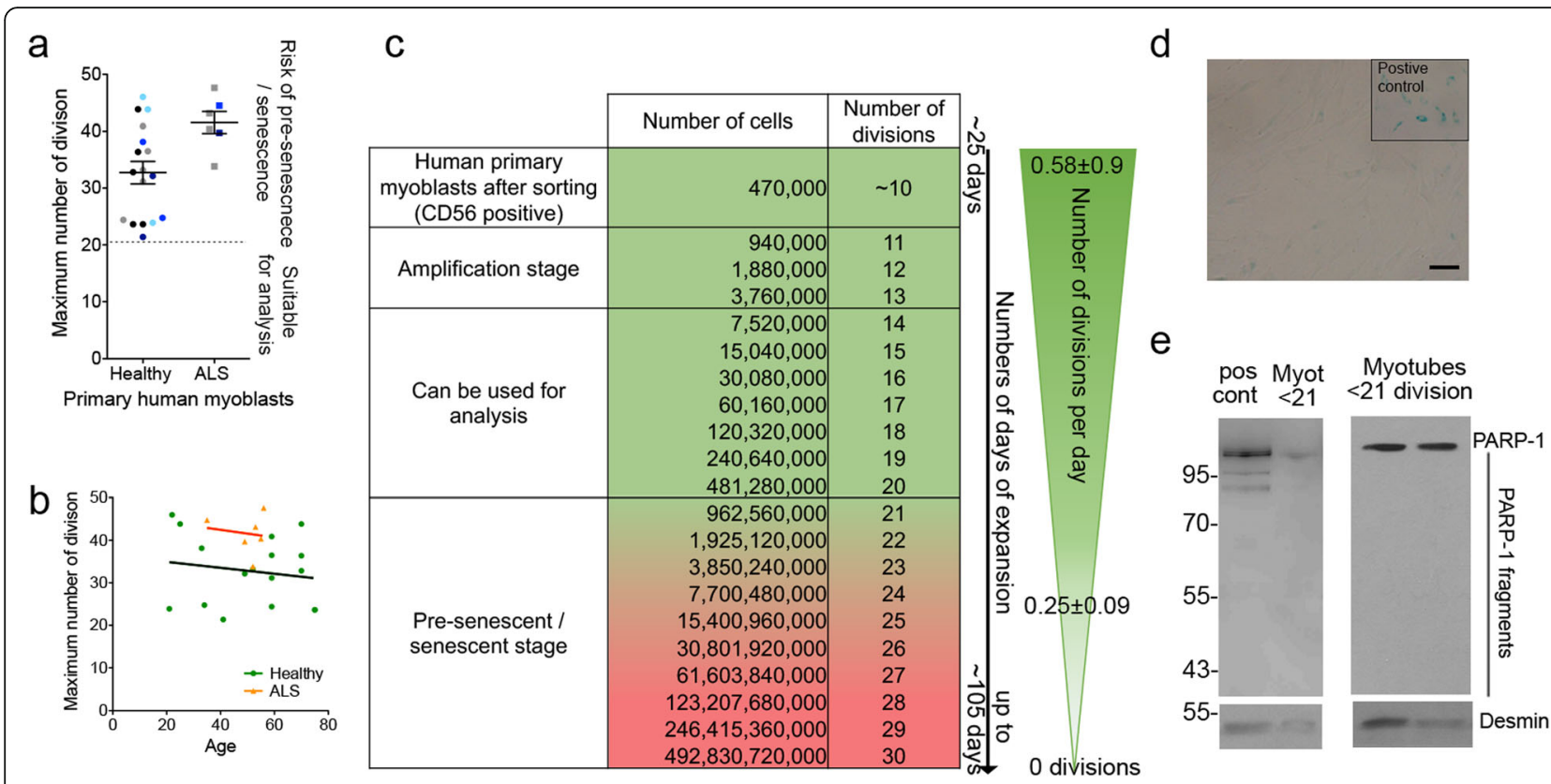

Fig. 1 Maximum number of divisions reached by primary human muscle cells, and the number of divisions required to obtain sufficient cell numbers: a Distribution of the maximum number of divisions that human muscle cells can execute. Each point represents one sample. Based on this number, a safe window to analyze fully active and proliferative muscle cells is under 21 divisions. Light blue: age 20-30, dark blue: age 30-40, gray: 40-50, black: 50-75 years old. $\mathbf{b}$ Absence of correlation between age and the maximum number of divisions. $\mathbf{c}$ Table showing the number of primary muscle cells obtained at different phases of cell culture. Typically, 470,000 CD56+ve muscle cells can be purified from a muscle biopsy culture after 10 divisions (first row, light green). The number of cells after each division and the number of divisions is given by row. Pink indicates the pre-senescence stage (based on the data in a) when cells may start to slow down their capacity to proliferate and then senesce (and rate of division drops from an average of 0.58 to 0.25 ). Importantly, for some subjects, the cells will not reach 30 divisions, as shown in plot 1a. Typical measurements of the number of days of expansion and of the average number of divisions per day are given on the right side of the table. $\mathbf{d}$ Myoblasts under 21 divisions were negative for beta-galactosidase. Top right panel: positive control of senescent cells positive for beta-galactosidase. Scale bar = $100 \mu \mathrm{m}$. e No cleaved PARP-1 was observed by Western blot, suggesting that myoblasts under 21 divisions do not show any sign of necrosis nor apoptosis

a

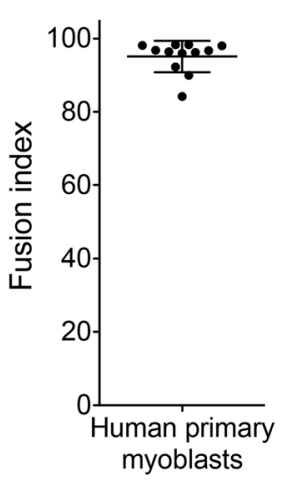

b

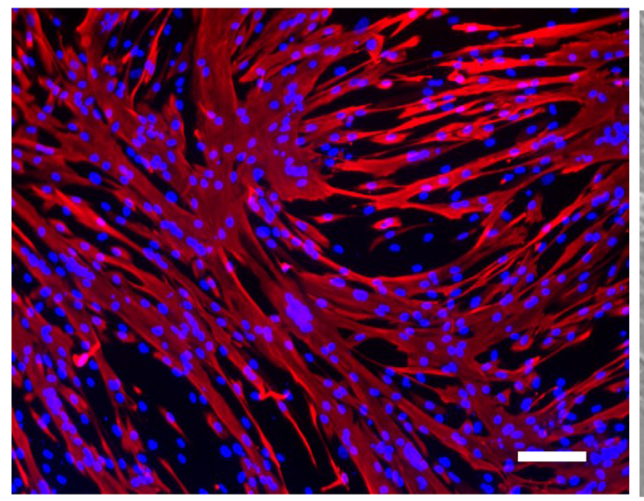

C

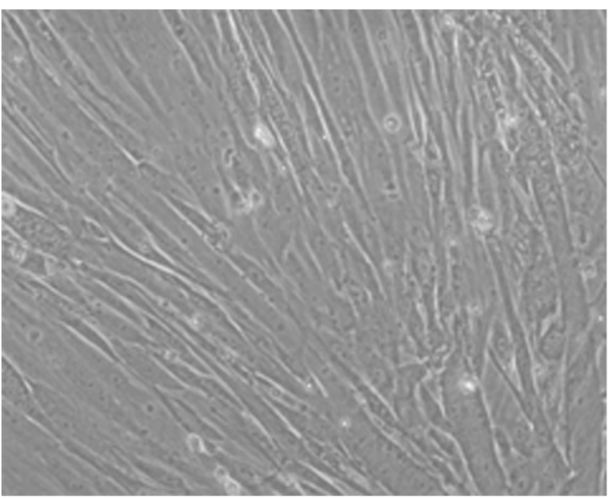

Fig. 2 Myoblasts at under 20 divisions differentiate efficiently and are not senescent. A total of 12 separate primary cell lines were cultured to under 21 divisions. a Dot-plot showing the percentage of primary human myoblasts fused into myotubes for 12 separate cell cultures, with an average fusion index calculated as $95.14 \% \pm 4.28$. b Representative images of myotubes positive for myosin heavy chain (in red), a marker of differentiation. Scale bar $=100 \mu \mathrm{m}$. c Over $80 \%$ of the flask is covered and no obvious signs of cell death are observed. Scale bar $=100 \mu \mathrm{m}$. 


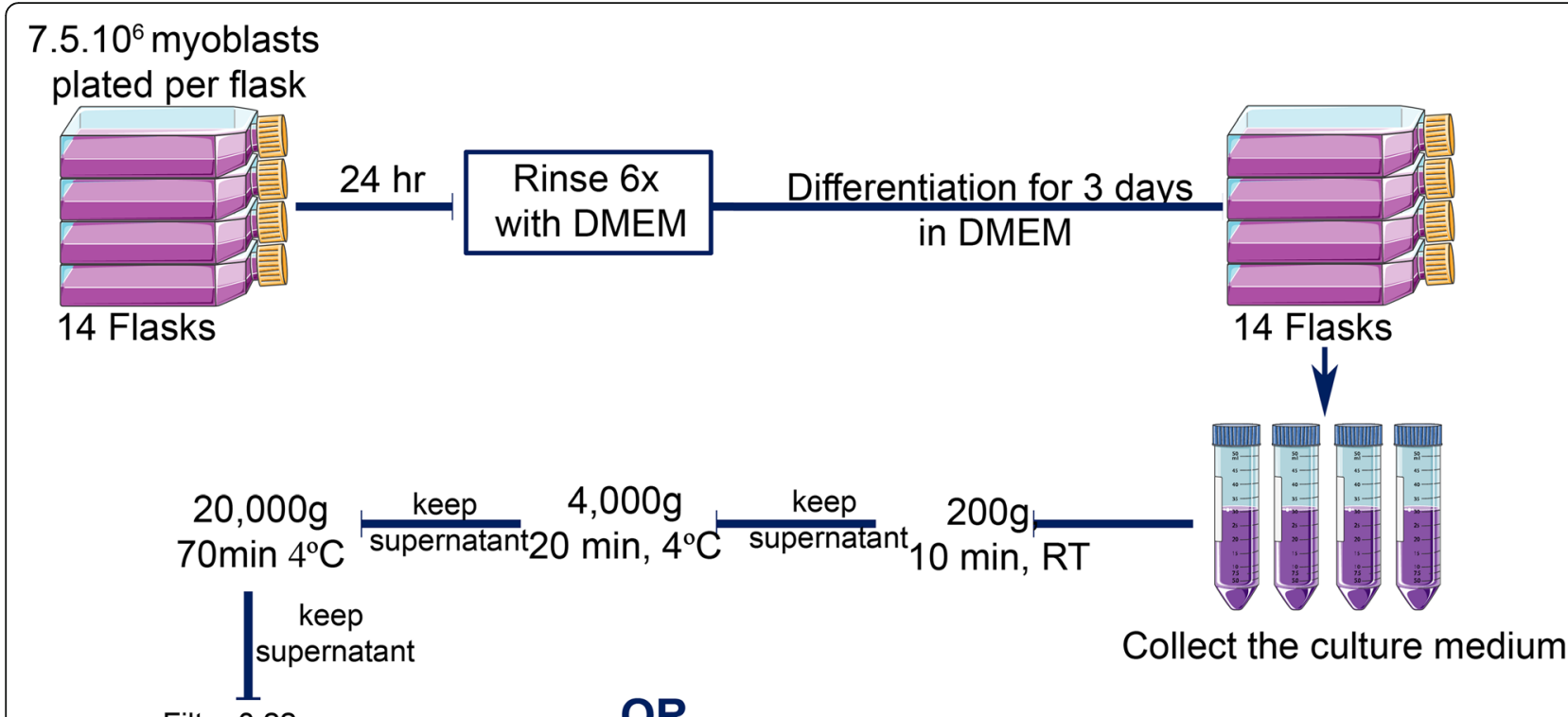

Filter $0.22 \mathrm{~mm}$

OR

1

Ultracentrifugation

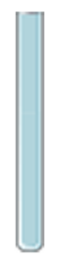

$100,000 \mathrm{~g}, 70 \mathrm{~min}, 4^{\circ} \mathrm{C}$

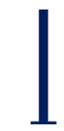

Rinse $3 \times$ with PBS

$100,000 \mathrm{~g}, 70 \mathrm{~min}, 4^{\circ} \mathrm{C}$

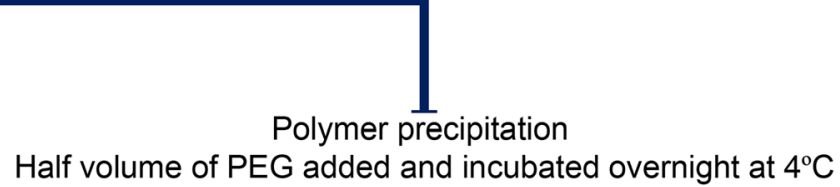

Half volume of PEG added and incubated overnight at $4^{\circ} \mathrm{C}$

$10,000 \mathrm{~g}, 70 \mathrm{~min}, 4^{\circ} \mathrm{C}$

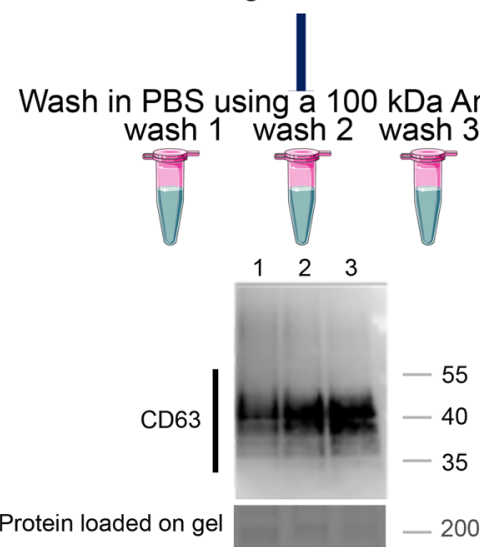

Fig. 3 Schema summarizing the protocols used to extract muscle exosomes from the primary human myotube culture medium, using either the ultracentrifugation or the modified polymer-precipitation strategy. For a single data point, 14 flasks of $225 \mathrm{~cm}^{2}$ are plated with $7.5 \times 10^{6}$ myoblasts. After $24 \mathrm{~h}$, once the myoblasts have attached to the flask, they are rinsed 6 times in DMEM and then differentiated into myotubes by cultivating them in DMEM. After $72 \mathrm{hr}$, the conditioned medium is collected for muscle exosome extraction. After removing dead cells (200 g, 10 min, RT), cell debris $\left(4000 \mathrm{~g}, 20 \mathrm{~min}, 4^{\circ} \mathrm{C}\right)$, and ectosomes $\left(20,000 \mathrm{~g}, 70 \mathrm{~min}\right.$ at $4^{\circ} \mathrm{C}$, and filtered at $\left.0.22 \mu \mathrm{m}\right)$, the cleared media is subjected to exosome extraction either by the ultracentrifugation protocol or by a modified polymer-precipitation protocol. Ultracentrifugation is at $100,000 \mathrm{~g}$ ( $\left.70 \mathrm{~min}, 4^{\circ} \mathrm{C}\right)$, which is followed by washing the pellets three times with PBS $\left(100,000 \mathrm{~g}, 70 \mathrm{~min}, 4^{\circ} \mathrm{C}\right)$. The subsequent pellet is then either resuspended in $100 \mu \mathrm{l}$ of PBS or in NUPAGE ${ }^{\mathrm{TM}}$ LDS sample buffer for western blot. For the modified polymer-precipitation protocol, the polymer is added at half the volume of the pre-cleared media and incubated overnight at $4^{\circ} \mathrm{C}$. The mix is then centrifuged at $10,000 \mathrm{~g}$ for $70 \mathrm{~min}$ at $4{ }^{\circ} \mathrm{C}$. The subsequent pellet is then washed 3 times in PBS using a $100 \mathrm{kDa}$ Amicon ${ }^{\oplus}$ filter column. Western blot shows the rescue of the epitope CD63 after 3 washes in PBS 
based precipitation show the same cup-shape structure by electron microscopy (Fig. 4a) and are positive for CD63, CD82 (Fig. 4 b,c) and CD81 (Fig.4c), and float at the same density (Fig. 4c). Similar sized vesicles were observed by electron microscopy and by NanoSight analysis (Fig. 4d). Importantly, the ultracentrifugation strategy was far less

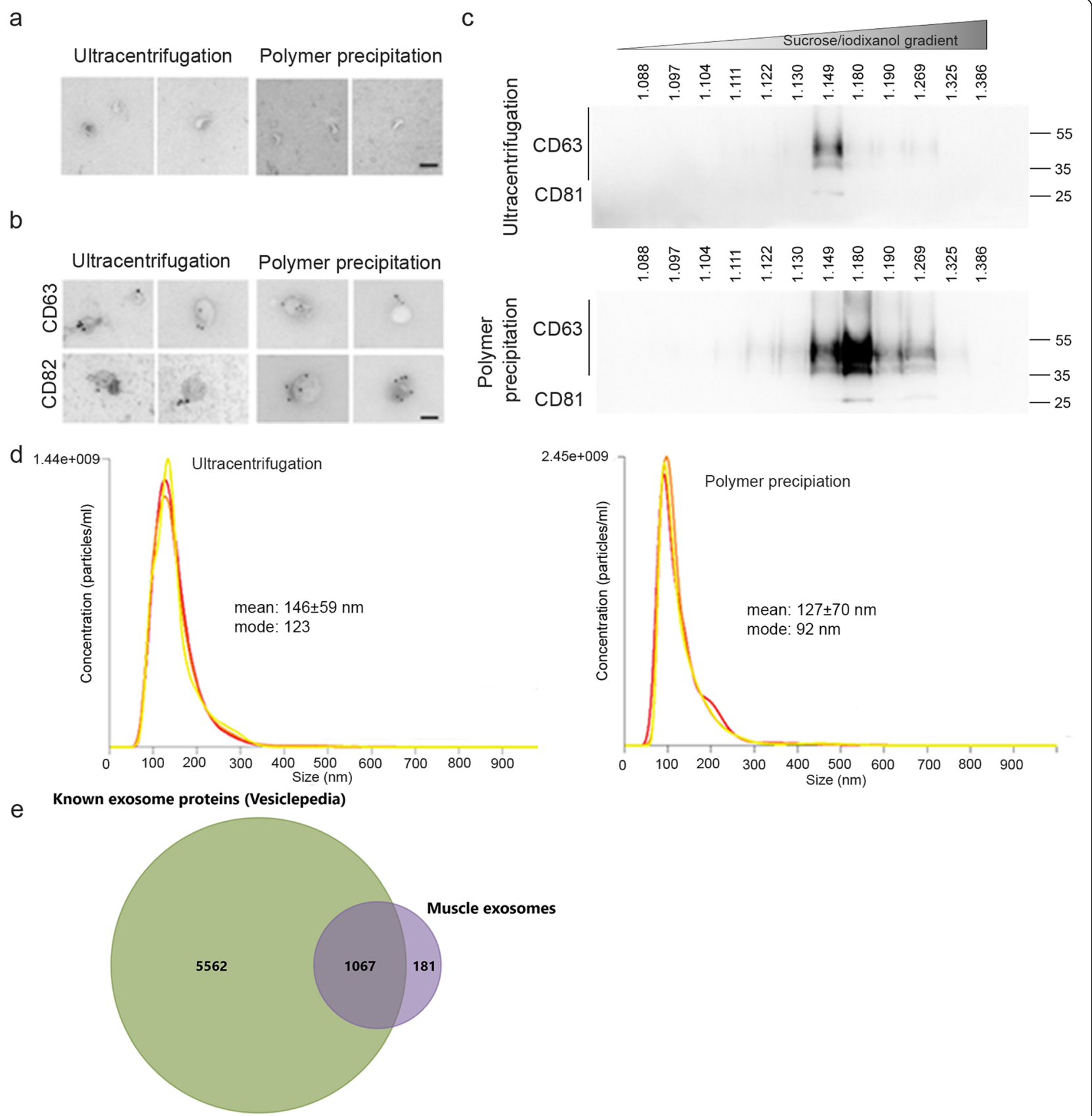

Fig. 4 Validation of exosome extraction strategy. For each experiment, exosomes were extracted from the culture medium of $100 \times 10^{6}$ myoblasts differentiated into myotubes for 3 days using either the ultracentrifugation or the polymer precipitation. The culture medium was non-supplemented DMEM (without serum). a Cup-shaped vesicles were observed by electron microscopy with both extraction protocols. bar $=100 \mathrm{~nm}$. b Both extractions show vesicles that are positive for CD63 and CD82 by electron microscopy. Bar $=100 \mathrm{~nm}$. c Exosome extracts were loaded on iodixanol gradients as described in material and methods. Western blot results are shown for CD63 and CD81 in twelve fractions for the iodixanol gradient. Top panel: exosomes extracted by ultracentrifugation. Bottom panel: exosomes extracted by polymer-based precipitation. Exosomes were detected at a density of 1.15-1.27 g.ml $\mathrm{ml}^{-1}$. d Nanosight analyses show similar-sized vesicles using both strategies, from 100-200 nm, with a greater number of particles being detected when using the polymer extraction. e Proteomic analysis of muscle exosomes. Venn diagram showing the overlap between muscle exosomes and proteins known to be detected by mass spectrometry in exosomes (Vesiclepedia, Exocarta database [36-39]) 
efficient than the polymer precipitation to extract exosomes as shown in Fig. 4c and d. A proteomic analysis revealed that the protein profile of the muscle vesicles extracted using the modified polymer-based precipitation is enriched in proteins known to be present in exosomes (Fig.4d) as given by Exocarta [36-39].

\section{Working with $>30$ times fewer myoblasts, the modified polymer precipitation strategy still efficiently extracts vesicles that can be used for follow up experiments}

Previous publications suggested that cell density may affect exosome secretion [46]. We thus tested different densities of differentiated myoblasts per $\mathrm{cm}^{2}$ and observed that the optimal conditions were 33,400 cells.cm ${ }^{-2}$ (Fig. 5a), thus $7.5 \times 10^{6}$ myoblasts for a 225 $\mathrm{cm}^{2}$ flask. Exosomes secreted by muscle cells were positive for CD63, CD81, Flotillin, HSPA8, and Alix (Fig. 5b). Exosomes extracted from $7.5 \times 10^{6}$ differentiated myoblasts could be used to explore exosome mRNA content (Fig. 5c) and could be used to isolate a specific subpopulation of exosomes such as CD63-positive vesicles (Fig. 5d). In addition, polymer-precipitated exosomes can be stained with PKH26 and applied to recipient cells such as myotubes or iPSC-derived motor neurons (Fig. 5e).

\section{Conclusion}

Although emphasis has been given to the role of the muscle tissue environment in regeneration (e.g., in parabiosis experiments $[47,48]$ ), very little is known about the secretome of human muscle cells. The role of muscle as a secretory endocrine organ has been recently proposed and a number of studies have characterized the secretory profiles of muscle cells $[5,7,32,49,50]$, but the role of muscle vesicles is an underexplored field, as is the putative cross-talk between different cell types. Exploring the content and function of vesicles secreted by purified human myoblasts will improve our understanding of how muscle communicates with its environment in different physiological (e.g., aging) and pathological contexts (e.g., neuromuscular disorders, cachexia associated with cancer, etc.) [51-54]. It may also provide new insights regarding the pathological mechanisms underlying such conditions and may help in the identification of novel biomarkers and novel therapeutic targets for diseases.

Only a small number of human muscle cells can be obtained from muscle biopsies and these cells have a very limited capacity to divide. These caveats, along with the fact that muscle cells do not secrete large quantities of vesicles-consistent with muscle accounting for up to $50 \%$ of body mass-reinforce the importance of identifying strategies that allow for the most efficient extraction of muscle vesicles from a small quantity of starting material.

Large amounts of starting material are required when using the ultracentrifugation-based technique [55], especially when there is an intention to perform downstream OMICS studies (e.g., proteomic, transcriptomic, metabolomic analyses; $250 \times 10^{6}$ muscle cells for one replicate [5]). Several commercial kits have been developed to improve isolation efficacy and speed. The purity of vesicles isolated using these kits is often questioned in comparison to the ultracentrifugation methodology, especially when extracting from serum/plasma $[56,57]$, but also in the in vitro context $[58,59]$. However, it is important to note that while these studies do adhere strictly to the manufacturers' instructions for the usage of the kits, they often fail to carry out identical sample preparations prior to the comparison-for example, carrying out centrifugations and/or filtration steps to remove microvesicles and other contaminants before ultracentrifugation but neglecting to do so before using the kits. This, together with the epitope hiding property of the polymer that is discussed below in the context of additional rinsing steps, may largely account for differences in observed contamination rates.

In the present study, muscle exosomes are extracted from differentiated human myoblasts that have been cultured in non-supplemented DMEM. This ensures that exosome preparations isolated using this method are fully depleted of any potential contaminants from culture medium additives such as fetal bovine serum. Furthermore, differentiated myoblasts cultured under these conditions undergo neither necroptosis nor apoptosis (current paper, [60]). When collecting the conditioned media, differential centrifugation steps and a filtration step are included to remove potential cell debris, apoptotic vesicles, and microvesicles. All of these precautions are carried out prior to the addition of the polymer solution, thus eliminating most, if not all potential contaminants and ensuring a highly purified isolation process, and we recommend that such steps are included no matter which subsequent exosome isolation method is used.

The absence of medium supplementation and the lack of necroptosis and apoptosis mean that the culture medium of differentiated human muscle cells is a noncomplex sample, and is therefore well-suited to the protocol described here, as opposed to the serum which includes many different types of the vesicle and a relatively complex molecular milieu, thereby making it difficult to isolate exosomes by size and density alone, and requiring additional approaches such as exosome pulldown to maximize purity $[61,62]$, but leading to the analysis of a specific circulating exosome subpopulation.

Looking at the literature, we noticed that the polymer kit consistently led to a greater number of vesicles 


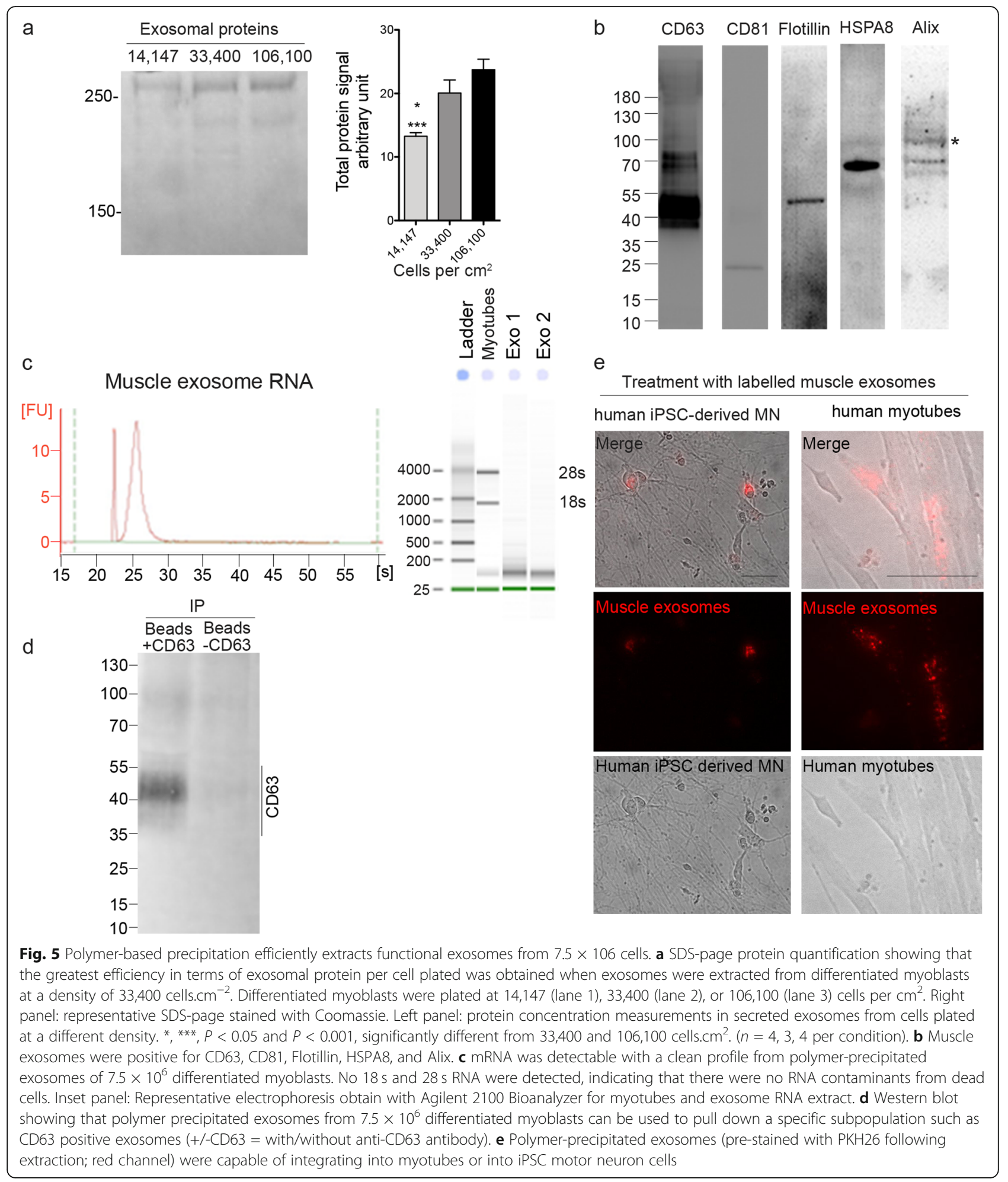

detected by NanoSight $[56,59,63]$, and yet led to a reduced detection of exosomal markers by Western blot [28, 45, 56, 59, 63, 64]. Interestingly, Rider et al. while optimizing a polymer to extract extracellular vesicles showed that rinsing of exosomes that had been precipitated using the polymer resulted in an increase in exosome markers detected by Western blot [28]. Based on that study, we decided to use $100 \mathrm{kDa}$ Amicon ${ }^{\circ}$ filter columns to add extra washes after precipitating the vesicles from pre-cleared media. These additional steps 
removed the surplus of the polymer [65], thereby rescuing the detection of exosomal markers (Fig. 3), and likely have the additional advantage of removing any cytokines [58] secreted by muscle cells. These extra rinsing step may also improve the functionality of the exosome-like vesicles, for experiments involving the incorporation of vesicles into recipient cells (Fig. 5e).

Pre-clearing the culture medium followed by polymer precipitation and three PBS washes allows the extraction of exosome-like vesicles while using 33 times less starting material than what is needed when the ultracentrifugation protocol is used, and the quality and functionality of extracted exosomes is retained. The option of being able to carry out proteomic and functional analyses on exosomes while requiring much fewer cell numbers as a starting point is a critically important asset especially when dealing with primary cell cultures that quickly senesce $[66,67]$.

\section{Acknowledgements}

We wish to thank Prof Pierre Francois Pradat for enabling access to fresh human muscle biopsies and Dr Cecile Martinat for enabling access to human iPSC motor neurons. We wish to thank Dr Kristy Brown for her help for the proteomic analysis.

\section{Authors' contributions}

SD conceptualized and supervised the study. LLG, ZGO, EA, and SD performed and analyzed the experiments. OC performed the CD63 exosome pull down. JL performed the electron microscopy analysis. LLG, GZO, EA, JL, GBB, WD, and SD wrote, discussed, and edited the paper. All authors read and approved the final manuscript.

\section{Funding}

This work was financed by European Union Regional Development Fund (ERDF) EU Sustainable Competitiveness Programme for N. Ireland, Northern Ireland Public Health Agency (HSC R\&D) \& Ulster University (PI: A Bjourson). LLG was a recipient of ArSLA PhD fellowship, GZO post-doctoral position was financed by INSERM/DGOS, EA was Ph.D VCRS Ulster University fellowship and OC was the recipient of Ph.D DELL fellowship.

\section{Availability of data and materials}

All data and materials will be available on demand.

\section{Ethics approval and consent to participate}

The protocol (NCT01984957) was approved by the local Ethical Committee. Written informed consent was obtained from all patients.

\section{Consent for publication}

All co-authors consent for publication

Competing interests

The authors declare that they have no conflict of interest.

\section{Author details}

${ }^{1}$ Northern Ireland Center for Stratified/Personalised Medicine, Biomedical Sciences Research Institute, Ulster University, Derry Londonderry, UK. ${ }^{2}$ Centre for Research in Myology, INSERM UMRS_974, Sorbonne Université, Paris, France.

Received: 5 April 2020 Accepted: 22 June 2020

Published online: 08 July 2020

\section{References}

1. Pedersen BK, Febbraio MA. Muscle as an endocrine organ: focus on musclederived interleukin-6. Physiol Rev [Internet]. 2008 [cited 2012 Oct 30];88: 1379-406. Available from: http://www.ncbi.nlm.nih.gov/pubmed/18923185.

2. Engler D. Hypothesis: Musculin is a hormone secreted by skeletal muscle, the body's largest endocrine organ. Evidence for actions on the endocrine pancreas to restrain the beta-cell mass and to inhibit insulin secretion and on the hypothalamus to co-ordinate the ne. Acta Biomed [Internet]. 2007 [cited 2012 Jul 30];78 Suppl 1:156-206. Available from: http://www.ncbi.nlm. nih.gov/pubmed/17465332.

3. Chan CYX, Masui O, Krakovska O, Belozerov VE, Voisin S, Ghanny S, et al. Identification of differentially regulated secretome components during skeletal myogenesis. Mol Cell Proteomics [Internet]. 2011 [cited 2012 Jul 30]; 10:M110.004804. Available from: http://www.pubmedcentral.nih.gov/ articlerender.fcgi? artid $=3098588 \&$ tool $=$ pmcentrez\&rendertype $=$ abstract.

4. Henningsen J, Rigbolt KTG, Blagoev B, Pedersen BK, Kratchmarova I. Dynamics of the skeletal muscle secretome during myoblast differentiation. Mol Cell Proteomics [Internet]. 2010 [cited 2012 Jul 30];9:2482-96. Available from: http://www.pubmedcentral.nih.gov/articlerender.fcgi?artid = 2984231 \&tool $=$ pmcentrez\&rendertype $=$ abstract.

5. Le Bihan M-C, Bigot A, Jensen SS, Dennis J, Rogowska-Wrzesinska A, Lainé J, et al. In-depth analysis of the secretome identifies three major independent secretory pathways in differentiating human myoblasts. J Proteomics [Internet]. 2012 [cited 2012 Oct 27];77:344-56. Available from: http://www. ncbi.nlm.nih.gov/pubmed/23000592.

6. Roca-Rivada A, Al-Massadi O, Castelao C, Senín LL, Alonso J, Seoane LM, et al. Muscle tissue as an endocrine organ: comparative secretome profiling of slow-oxidative and fast-glycolytic rat muscle explants and its variation with exercise. J Proteomics [Internet]. 2012 [cited 2012 Oct 30];75:5414-25. Available from: http://www.ncbi.n/m.nih.gov/pubmed/22800642.

7. Yoon JH, Kim J, Song P, Lee TG, Suh P-G, Ryu SH. Secretomics for skeletal muscle cells: a discovery of novel regulators? Adv Biol Regul [Internet]. 2012 [cited 2012 Oct 31];52:340-50. Available from: http://www.ncbi.nlm.nih.gov/ pubmed/22781747.

8. Hutcheson JD, Aikawa E. Extracellular vesicles in cardiovascular homeostasis and disease. Curr Opin Cardiol. 2018.

9. Machtinger R, Laurent LC, Baccarelli AA. Extracellular vesicles: Roles in gamete maturation, fertilization and embryo implantation. Hum. Reprod. Update. 2016.

10. Kreger BT, Johansen ER, Cerione RA, Antonyak MA. The enrichment of survivin in exosomes from breast cancer cells treated with paclitaxe promotes cell survival and chemoresistance. Cancers (Basel). 2016;.

11. Buzas El, György B, Nagy G, Falus A, Gay S. Emerging role of extracellular vesicles in inflammatory diseases. Nat. Rev. Rheumatol. 2014.

12. Rome S, Forterre A, Mizgier ML, Bouzakri K. Skeletal muscle-released extracellular vesicles: State of the art. Front. Physiol. 2019.

13. Becker A, Thakur BK, Weiss JM, Kim HS, Peinado H, Lyden D. Extracellular vesicles in cancer: cell-to-cell mediators of metastasis. Cancer Cell. 2016.

14. Pan BT, Teng K, Wu C, Adam M, Johnstone RM. Electron microscopic evidence for externalization of the transferrin receptor in vesicular form in sheep reticulocytes. J Cell Biol [Internet]. 1985 [cited 2012 Oct 31];101:942-8. Available from: http://www.pubmedcentral.nih.gov/articlerender.fcgi?artid = 2113705\&tool $=$ pmcentrez\&rendertype $=$ abstract

15. Kalra H, Drummen G, Mathivanan S, Kalra H, Drummen GPC, Mathivanan S. Focus on Extracellular Vesicles: Introducing the Next Small Big Thing. Int J Mol Sci. Multidisciplinary Digital Publishing Institute; 2016;17:170.

16. Raposo G, Stoorvogel W. Extracellular vesicles: exosomes, microvesicles, and friends. J Cell Biol. 2013;200:373-83.

17. Antonyak MA, Li B, Boroughs LK, Johnson JL, Druso JE, Bryant KL, et al. Cancer cell-derived microvesicles induce transformation by transferring tissue transglutaminase and fibronectin to recipient cells. Proc Natl Acad Sci U S A [Internet]. 2011 [cited 2012 Oct 31];108:4852-7. Available from: http://www.pubmedcentral.nih.gov/articlerender.fcgi?artid=306435 9\&tool=pmcentrez\&rendertype = abstract.

18. Théry C, Ostrowski M, Segura E. Membrane vesicles as conveyors of immune responses. Nat Rev Immunol [Internet]. 2009 [cited 2012 Oct 9];9: 581-93. Available from: http://www.ncbi.nlm.nih.gov/pubmed/19498381.

19. Spencer MJ, Croall DE, Tidball JG. Calpains are activated in necrotic fibers from mdx dystrophic mice. J Biol Chem [Internet]. 1995 [cited 2012 Jul 30];270: 10909-14. Available from: http://www.ncbi.nlm.nih.gov/pubmed/7738032.

20. Malerba A, Sharp PS, Graham IR, Arechavala-Gomeza V, Foster K, Muntoni F, et al. Chronic systemic therapy with low-dose morpholino oligomers ameliorates the pathology and normalizes locomotor behavior in $\mathrm{mdx}$ mice. Mol Ther [Internet]. 2011 [cited 2012 Oct 4];19:345-54. Available from: http://www.pubmedcentral.nih.gov/articlerender.fcgi?artid=3034854\&tool= pmcentrez\&rendertype=abstract.

21. Bencze M, Negroni E, Vallese D, Yacoub-Youssef $H$, Chaouch S, Wolff A, et al. Proinflammatory macrophages enhance the regenerative capacity of 
human myoblasts by modifying their kinetics of proliferation and differentiation. Mol Ther [Internet]. 2012 [cited 2012 Oct 18]; Available from: http://www.ncbi.nlm.nih.gov/pubmed/23070116.

22. Bobrie A, Colombo M, Raposo G, Théry C. Exosome secretion: molecular mechanisms and roles in immune responses. Traffic [Internet]. 2011 [cited 2012 Oct 31];12:1659-68. Available from: http://www.ncbi.nlm.nih.gov/ pubmed/21645191.

23. Nehlin JO, Just M, Rustan AC, Gaster M. Human myotubes from myoblast cultures undergoing senescence exhibit defects in glucose and lipid metabolism. Biogerontology. 2011:

24. Théry C, Amigorena S, Raposo G, Clayton A. Isolation and characterization of exosomes from cell culture supernatants and biological fluids. Curr Protoc Cell Biol [Internet]. 2006 [cited 2012 Jul 30];Chapter 3:Unit 3.22. Available from: http://www.ncbi.nlm.nih.gov/pubmed/18228490.

25. Raposo G, Nijman HW, Stoorvogel W, Leijendekker R, Hardingfl Cornelis C, Melief JM, et al. B lymphocytes secrete antigen-presenting vesicles; 1996.

26. Colombo M, Raposo G, Théry C. Biogenesis, secretion, and intercellular interactions of exosomes and other extracellular vesicles. Annual Reviews. 2014;30:255-89.

27. Hessvik NP, Llorente A. Current knowledge on exosome biogenesis and release. Cell Mol Life Sci Springer. 2018;75:193-208.

28. Rider MA, Hurwitz SN, Meckes DG. ExtraPEG: a polyethylene glycol-based method for enrichment of extracellular vesicles. Sci Rep. 2016;6:23978.

29. Théry C, Witwer KW, Aikawa E, Alcaraz MJ, Anderson JD, Andriantsitohaina $\mathrm{R}$, et al. Minimal information for studies of extracellular vesicles 2018 (MISEV2018): a position statement of the International Society for Extracellular Vesicles and update of the MISEV2014 guidelines. J Extracell vesicles [Internet]. 2018 [cited 2019 Sep 19];7:1535750. Available from: https://www.tandfonline.com/doi/ full/10.1080/20013078.2018.1535750.

30. Yu LL, Zhu J, Liu JX, Jiang F, Ni WK, Qu LS, et al. A comparison of traditional and novel methods for the separation of exosomes from human samples. Biomed Res. Int. 2018.

31. Bigot A, Duddy WJ, Ouandaogo ZG, Negroni E, Mariot V, Ghimbovschi S, et al. Age-associated methylation suppresses SPRY1, leading to a failure of re-quiescence and loss of the reserve stem cell pool in elderly muscle. Cell Rep [Internet]. 2015;13:1172-82 Available from: http://www.ncbi.nlm.nih. gov/pubmed/26526994.

32. Duguez S, Duddy W, Johnston H, Lainé J, Le Bihan MCMC, Brown KJKJ, et al. Dystrophin deficiency leads to disturbance of LAMP1-vesicle-associated protein secretion. Cell Mol Life Sci [Internet]. 2013 [cited 2013 Nov 2];70: 2159-74. Available from: http://www.ncbi.nlm.nih.gov/pubmed/23344255.

33. Schröder M, Schäfer R, Friedl P. Spectrophotometric determination of iodixanol in subcellular fractions of mammalian cells. Anal Biochem. Academic Press Inc.; 1997;244:174-176.

34. Welton JL, Brennan P, Gurney M, Webber JP, Spary LK, Carton DG, et al. Proteomics analysis of vesicles isolated from plasma and urine of prostate cancer patients using a multiplex, aptamer-based protein array. J Extracell Vesicles [Internet]. 2016;5:31209. Available from: https://www.tandfonline. com/doi/full/10.3402/jev.v5.31209.

35. Welton JL, Loveless S, Stone T, von Ruhland C, Robertson NP, Clayton A. Cerebrospinal fluid extracellular vesicle enrichment for protein biomarker discovery in neurological disease; multiple sclerosis. J Extracell Vesicles [Internet]. 2017;6:1369805. Available from: https://www.tandfonline.com/doi/ full/10.1080/20013078.2017.1369805.

36. Keerthikumar S, Chisanga D, Ariyaratne D, Al Saffar H, Anand S, Zhao K, et al. ExoCarta: A web-based compendium of exosomal cargo. J Mol Biol [Internet]. 2016;428:688-92. Available from: https://linkinghub.elsevier.com/ retrieve/pii/S0022283615005422.

37. Simpson RJ, Kalra H, Mathivanan S, et al. J Extracell Vesicles [Internet]. 2012;1:18374 Available from: https:/www.tandfonline.com/doi/full/10.3402/jev.v1i0.18374.

38. Mathivanan S, Fahner CJ, Reid GE, Simpson RJ. ExoCarta 2012: database of exosomal proteins, RNA and lipids. Nucleic Acids Res [Internet]. 2012;40: D1241-4 Available from: https://academic.oup.com/nar/article-lookup/doi/1 $0.1093 /$ nar/gkr828

39. Mathivanan S, Simpson RJ. ExoCarta: a compendium of exosomal proteins and RNA. Proteomics [Internet]. 2009;9:4997-5000 Available from: http://doi. wiley.com/10.1002/pmic.200900351

40. Maury Y, Côme J, Piskorowski RA, Salah-Mohellibi N, Chevaleyre V, Peschanski $\mathrm{M}$, et al. Combinatorial analysis of developmental cues efficiently converts human pluripotent stem cells into multiple neuronal subtypes. Nat
Biotechnol [Internet]. 2014 [cited 2014 Nov 11];33:89-96. Available from: http://www.ncbi.nlm.nih.gov/pubmed/25383599.

41. Bigot A, Duddy WJ, Ouandaogo ZG, Negroni E, Mariot V, Ghimbovschi S, et al. Age-associated methylation suppresses SPRY1, leading to a failure of re-quiescence and loss of the reserve stem cell pool in elderly muscle. Cell Rep. 2015;13.

42. Riquelme JA, Takov K, Santiago-Fernández C, Rossello X, Lavandero S, Yellon DM, et al. Increased production of functional small extracellular vesicles in senescent endothelial cells. J Cell Mol Med. Blackwell Publishing Inc;; 2020; jcmm.15047.

43. Graves SI, Baker DJ. Implicating endothelial cell senescence to dysfunction in the ageing and diseased brain. Basic Clin Pharmacol Toxicol. John Wiley \& Sons, Ltd; 2020;n/a.

44. Choi E-J, Kil IS, Cho E-G. Extracellular vesicles derived from senescent fibroblasts attenuate the dermal effect on keratinocyte differentiation. Int J Mol Sci. Multidisciplinary Digital Publishing Institute; 2020;21:1022.

45. Patel GK, Khan MA, Zubair H, Srivastava SK, Khushman M, Singh S, et al. Comparative analysis of exosome isolation methods using culture supernatant for optimum yield, purity and downstream applications. Sci Rep. Nature Publishing Group; 2019;9:5335.

46. Gudbergsson JM, Johnsen KB, Skov MN, Duroux M. Systematic review of factors influencing extracellular vesicle yield from cell cultures. Cytotechnology. Springer Netherlands; 2016. p. 579-92.

47. Conboy IM, Conboy MJ, Wagers AJ, Girma ER, Weissman IL, Rando TA. Rejuvenation of aged progenitor cells by exposure to a young systemic environment. Nature [Internet]. 2005 [cited 2013 Sep 23];433:760-4. Available from: http://www.ncbi.nlm.nih.gov/pubmed/15716955.

48. Rando TA, Chang HY. Aging, rejuvenation, and epigenetic reprogramming: resetting the aging clock. Cell [Internet]. 2012 [cited 2013 Nov 7];148:46-57. Available from: http://www.pubmedcentral.nih.gov/articlerender.fcgi?artid = 3336960\&tool $=$ pmcentrez\&rendertype $=$ abstract.

49. Forterre A, Jalabert A, Berger E, Baudet M, Chikh K, Errazuriz E, et al, Proteomic analysis of $\mathrm{C} 2 \mathrm{C} 12$ myoblast and myotube exosome-like vesicles: a new paradigm for myoblast-myotube cross talk? PLoS One [Internet]. 2014 [cited 2015 Jan 10];::e84153. Available from: http://www. pubmedcentral.nih.gov/articlerender.fcgi?artid $=$ 3879278\&tool= pmcentrez\&rendertype $=$ abstract.

50. Pedersen BK, Febbraio MA. Muscles, exercise and obesity: skeletal muscle as a secretory organ. Nat Rev Endocrinol [Internet]. 2012 [cited 2012 Oct 30];8: 457-65. Available from: http://www.ncbi.nlm.nih.gov/pubmed/22473333.

51. Kuang S, Gillespie MA, Rudnicki MA. Niche regulation of muscle satellite cell self-renewal and differentiation. Cell Stem Cell [Internet]. 2008 [cited 2014 Aug 29];2:22-31. Available from: http://www.ncbi.nlm.nih.gov/pubmed/18371418.

52. Barberi L, Scicchitano BM, De Rossi M, Bigot A, Duguez S, Wielgosik A, et al. Age-dependent alteration in muscle regeneration: the critical role of tissue niche. Biogerontology [Internet]. 2013 [cited 2013 Nov 2];14:273-92. Available from: http://www.pubmedcentral.nih.gov/articlerender.fcgi?artid= 3719007\&tool=pmcentrez\&rendertype $=$ abstract.

53. Thorley M, Malatras A, Duddy WJ, Le Gall L, Mouly V, Butler Browne G, et al. Changes in communication between muscle stem cells and their environment with aging. J Neuromuscul Dis [Internet]. 2015;2:in press. Available from: http://www.medra.org/servlet/aliasResolver?alias= iospress\&doi=10.3233/JND-150097.

54. Vijayakumar UG, Milla V, Cynthia Stafford MY, Bjourson AJ, Duddy W, Duguez SM-R. A Systematic Review of Suggested Molecular Strata, Biomarkers and Their Tissue Sources in ALS. Front Neurol [Internet]. Frontiers; 2019 [cited 2019 May 6];10:400. Available from: https://www frontiersin.org/articles/10.3389/fneur.2019.00400/abstract.

55. Zeringer E, Barta T, Li M, Vlassov AV. Strategies for isolation of exosomes. Cold Spring Harb Protoc. 2015;2015:319-23.

56. Tian $\mathrm{Y}$, Gong M, Hu Y, Liu H, Zhang W, Zhang M, et al. Quality and efficiency assessment of six extracellular vesicle isolation methods by nanoflow cytometry. J Extracell Vesicles. 2020.

57. Takov K, Yellon DM, Davidson SM. Comparison of small extracellular vesicles isolated from plasma by ultracentrifugation or size-exclusion chromatography: yield, purity and functional potential. J Extracell Vesicles. 2019.

58. Shu S La, Yang Y, Allen CL, Hurley E, Tung KH, Minderman $\mathrm{H}$, et al. Purity and yield of melanoma exosomes are dependent on isolation method. J Extracell Vesicles. 2020;

59. Lobb RJ, Becker M, Wen SW, Wong CSF, Wiegmans AP, Leimgruber A, et al. Optimized exosome isolation protocol for cell culture supernatant and human plasma. J Extracell Vesicles. 2015; 
60. Xiao R, Ferry AL, Dupont-Versteegden EE. Cell death-resistance of differentiated myotubes is associated with enhanced anti-apoptotic mechanisms compared to myoblasts. Apoptosis. 2011;16:221-34.

61. Greening DW, Xu R, Ji H, Tauro BJ, Simpson RJ. A protocol for exosome isolation and characterization: evaluation of ultracentrifugation, densitygradient separation, and immunoaffinity capture methods. Methods Mol Biol. 2015.

62. Winston CN, Romero HK, Ellisman M, Nauss S, Julovich DA, Conger T, et al. Assessing neuronal and astrocyte derived exosomes from individuals with mild traumatic brain injury for markers of neurodegeneration and cytotoxic activity. Front Neurosci. 2019;

63. Freitas D, Balmaña M, Poças J, Campos D, Osório H, Konstantinidi A, et al. Different isolation approaches lead to diverse glycosylated extracellular vesicle populations. J Extracell Vesicles. 2019.

64. Tang YT, Huang YY, Zheng L, Qin SH, Xu XP, An TX, et al. Comparison of isolation methods of exosomes and exosomal RNA from cell culture medium and serum. Int J Mol Med. 2017;

65. Ludwig A-K, De Miroschedji K, Doeppner TR, Börger V, Ruesing J, Rebmann $V$, et al. Precipitation with polyethylene glycol followed by washing and pelleting by ultracentrifugation enriches extracellular vesicles from tissue culture supernatants in small and large scales. J Extracell Vesicles. Taylor \& Francis; 2018;7:1528109.

66. Lehmann BD, Paine MS, Brooks AM, McCubrey JA, Renegar RH, Wang R, et al. Senescence-associated exosome release from human prostate cancer cells. Cancer Res. 2008;

67. Beer L, Zimmermann M, Mitterbauer A, Ellinger A, Gruber F, Narzt MS, et al. Analysis of the secretome of apoptotic peripheral blood mononuclear cells: impact of released proteins and exosomes for tissue regeneration. Sci Rep. 2015.

\section{Publisher's Note}

Springer Nature remains neutral with regard to jurisdictional claims in published maps and institutional affiliations.

Ready to submit your research? Choose BMC and benefit from:

- fast, convenient online submission

- thorough peer review by experienced researchers in your field

- rapid publication on acceptance

- support for research data, including large and complex data types

- gold Open Access which fosters wider collaboration and increased citations

- maximum visibility for your research: over $100 \mathrm{M}$ website views per year

At $\mathrm{BMC}$, research is always in progress.

Learn more biomedcentral.com/submissions 